\title{
Developing an Interactive Digital Handout for Momentum and Impulse Material Physics in High Schools
}

\author{
Ridho Pahlawan \\ Magister of Educational Technology, Sriwijaya University, Indonesia \\ e-mail: ridhopahlawaan@gmail.com \\ Ismet \\ Magister of Educational Technology, Sriwijaya University, Indonesia \\ e-mail: ismet_physicunsri@yahoo.com \\ Syarifuddin \\ Magister of Educational Technology, Sriwijaya University, Indonesia \\ e-mail: syarifuddin.unsri@gmail.com
}

\section{A R T I C L E I N F O \\ Article history: \\ 25 December 2020 \\ Received in revised form \\ 01 January 2021 \\ Accepted 25 January 2021 \\ Available online 03 February 2021 \\ Kata Kunci: \\ Handout Digital Interaktif, \\ Hasil Pembelajaran \\ Keywords: \\ Interactive Digital Handouts, \\ Learning Outcomes}

\begin{abstract}
A B S T R A K
Pengertian pelajaran fisika umumnya disebabkan oleh kurangnya bahan ajar inovatif yang memfasilitasi pembelajaran. Penelitian ini bertujuan untuk mengembangkan materi digital interaktif tentang momentum dan fisika impuls di sekolah menengah. Penelitian ini merupakan penelitian pengembangan dengan menggunakan model pengembangan Allesi dan Trollip. Prosedur penelitian dan pengembangan ini melalui 3 tahap, yaitu perencanaan, perancangan, dan pengembangan. Teknik pengumpulan data menggunakan observasi, wawancara, dan tes. Instrumen yang digunakan dalam mengumpulkan data adalah angket. Subyek penelitian ini adalah siswa kelas X SMA. Teknik analisis data yang digunakan adalah analisis kualitatif dan kuantitatif. Hasil penelitian berupa rata-rata hasil belajar sebelum diberikan tampilan handout digital interaktif momentum dan impuls materi fisika sebesar 48,93. Kemudian pendidik diajar menggunakan handout fisika digital interaktif menggunakan aplikasi articulate storyline untuk meningkatkan skor rata-rata hasil belajar kognitif siswa menjadi 81,27. Peningkatan nilai rata-rata siswa diukur dengan menggunakan skor N-gain, dan hasilnya 0,70 termasuk dalam kategori sedang. Dapat disimpulkan bahwa perangkat e-learning telah teruji efektif untuk meningkatkan hasil belajar siswa. Penelitian ini
\end{abstract} mengimplikasikan bahwa perangkat e-learning yang dikembangkan dapat digunakan untuk membantu siswa dalam belajar.

\begin{abstract}
A B S T R A C T
Understanding physics lessons is generally caused by the lack of innovative teaching materials that facilitate learning. This study aims to develop interactive digital material on momentum and impulse physics in high schools. This research is development research using the Allesi and Trollip development model. This research and development procedure goes through 3 stages, namely planning, design, and development. The techniques used to collect data were observation, interviews, and tests. The instrument used in collecting data was a questionnaire. The subjects of this study were tenth-grade senior high school students. The techniques used to analyze the data are qualitative and quantitative analysis. The study results were the average learning outcome before being given an interactive digital handout display of the momentum and impulses of physics material was 48.93. Then the educators taught using interactive digital physics handouts using the articulate storyline application to increase the average score of students' cognitive learning outcomes to 81.27 . The increase in the average score of students was measured using the $\mathrm{N}$-gain score, and the result was 0.70 in the moderate category. It can be concluded that e-learning tools have been tested effectively to improve student learning outcomes. This research implies that the developed e-learning tools can be used to help students in learning.
\end{abstract}

\section{Introduction}

The Industrial Revolution era 4.0 experienced rapid and competitive development marked by increased connectivity, interaction, and digital, artificial, and virtual intelligence systems. The use of industrial development 4.0 is increasingly complex with the presence of information technology in various sectors of life, one of which is the education system in Indonesia (Lase, 2019; Willya, Poluakan, Dikayuana, Wibowo, \& Raharjo, 2019). Revolutionary Education 4.0 is a program to support the realization of smart education through increasing and equalizing the quality of education, expanding access, and the relevance of using technology in realizing world-class education to produce students who have at least 4 21st century skills: collaboration, communication, critical and creative thinking, referring to on global competency standards in preparing young 
people to enter global work realities (Izati, Wahyudi, \& Sugiyarti, 2018; Meilani, Dantes, \& Tika, 2020). Optimizing the use of information technology as a means of education is expected to create effective and efficient learning so that learning objectives can be achieved to improve the quality of education properly.

The use of information technology developments has become a necessity in the world of education. The shift in the paradigm of using print learning resources to become digital learning sources can be seen from the shift in using print learning resources. The systems used in education include interactive-based teaching materials, electronic books, e-learning, and a Computer Based Test (CBT) based examination system. Kimianti \& Prasetyo (2019) stated that using information technology as a teaching material aims to motivate students to learn to become more active and enjoyable. In addition, the integration of information technology can improve the understanding of concepts so that learning is more effective and efficient for students (Muhson, 2010; Warsihna, 2016). Students will easily accept information technology in education if they pay attention to the needs following student characteristics. The development of the learning characteristics of senior high school students in the 4.0 era refers to generation $\mathrm{Z}$, which is synonymous with the term i-generation, net generation, or internet generation. In this generation, students live in a digital era with easy access to everything using sophisticated technology (Rastati, 2018; Subandowo, 2017). Generation Z has the characteristic of students living in line with the growing digital-based media and increasingly sophisticated technology with the ease of accessing the internet without borders. Thus, generation $\mathrm{Z}$ grows and grows with various internet-based applications that can support their life, especially in the learning process. It affects the development of behavior, personality, even education and student learning outcomes (Purnomo, Ratnawati, \& Aristin, 2016). Therefore, the use of technology in the learning process must be used appropriately to improve the quality of learning experienced by students to achieve learning objectives (Diani \& Niken, 2018; Wulandari, Sudatha, \& Simamora, 2020).

Today's problems are the lack of technology as a learning media (Hafsah, Rohendi, \& Purnawan, 2016; Muhson, 2010). This problem also occurs in one high school. Based on the preliminary study results in an interview at SMA Negeri 5 Talang Ubi with the Vice Principal for Curriculum and Physics Teachers. It was found that there was a school policy that allowed students to bring smartphones to school to support the learning process. In addition, there are wifi facilities that schools in the learning process use, but policies and learning support facilities are not widely used in learning resources, especially in physics learning. It can be seen from the explanation of the physics subject teacher, who explained that it is very rare to use information technology-based teaching materials in the learning process. Based on the results of a preliminary study in the form of observations in students using google form. It was found that the use of interactive digital handouts in learning was not optimal, which was supported by observations of 30 tenth-grade student respondents at SMA Negeri 5 Talang Ubi. It is known that $73.33 \%$ of students expressed difficulties in learning and understanding the concepts of physics. And $86.66 \%$ of students stated that they needed solutions in the form of digital teaching materials rather than printed teaching materials, $93.30 \%$ of students needed physics interactive digital handouts to enrich their knowledge in understanding the explanations from educators.

Based on these problems, students need teaching materials that are attractive, innovative, and easy to use to convey messages and appropriate visualizations to understand students (Irwandani, Latifah, Asyhari, Muzannur, \& Widayanti, 2017a; Pramana, Jampel, \& Pudjawan, 2020). For this reason, it is necessary to develop teaching materials in the form of interactive digital handouts whose contents are more focused on discussing the concepts of physics subject matter in their application in the field of technology. In the current era of globalization, interactive digital handout presentations can be in digital form as a form of technological advancement. Teaching materials are all forms of material used to assist educators in carrying out the learning process in the classroom (Fadillah \& Jamilah, 2016; Syafii, 2017). Teaching materials are a collection of materials arranged systematically to create an environment and an atmosphere that allows students to learn (Diantari, Damayanthi, Sugihartini, \& Wirawan, 2018; Udayana, Wirawan, \& Divayana, 2017). So teaching materials are all forms of material that can support learning. One form of teaching material is handouts. Handouts are teaching materials made by educators that aim to enrich the knowledge of students. Handouts are divided into two categories, namely printed handouts and digital handouts. Digital handouts have the advantage of displaying some material using interactive learning (Asrial, Syahrial, Maison, Kurniawan, \& Piyana, 2020; Kimianti \& Prasetyo, 2019).

Research on the development of teaching materials in interactive digital handouts on physics lessons refers to several journals, including teaching materials based on articulate storylines (Irwandani, Latifah, Asyhari, Muzannur, \& Widayanti, 2017b). The development of an interactive digital module based on articulate studio '13 in physics of circular motion material can be used as a valid and practical learning module. Yasin \& Ducha (2017) conducted a theoretical feasibility study of interactive multimedia based on the articulate storyline material on the human reproductive system in the eleventh grade of senior high school. To produce interactive multimedia based on the articulate storyline on human reproductive system material is theoretically feasible based on media validity. Develop interactive multimedia based on articulate storylines that are valid, practical, 
and potentially affect the increase of student motivation in Senior High School. Rafmana \& Chotimah (2018) develop interactive multimedia based on articulate storylines that are valid, practical, and can potentially affect the increase in senior high school student motivation.

Based on this research, it can be concluded that the development of teaching materials in the form of interactive digital handouts can improve student learning outcomes. This study aims to develop interactive digital material on momentum and impulse physics in high schools. It is hoped that the developed interactive digital material can help students learn to improve student learning outcomes.

\section{Method}

This development research uses the development model used, namely Alessi \& Trollip (2001). This research and development were carried out at SMA Negeri 5 Talang Ubi, Penukal Abab, Lematang Ilir Regency in stages. This research was conducted in the 2019/2020 school year. The research subjects at the design and product development stage were physics interactive digital handouts. The research subjects in the field test stage were tenth-grade students of SMA Negeri 5 Talang Ubi.

The techniques used to collect data were observation, interviews, and tests. The instrument used to collect data was a questionnaire. Three (three) validators validated the physics interactive digital handout was validated by 3 (three) validators from learning design, materials, and media. The practicality of the physics interactive digital handout was also evaluated by the tenth-grade students of SMA Negeri 5 Talang Ubi. The effectiveness of the physics interactive digital handout was evaluated from the results of field tests conducted by 30 students.

This research and development procedure goes through 3 important stages, namely planning, design, and development. The complete multimedia development process, according to Alessi \& Trollip (2001) shown in Figure 1.

\begin{tabular}{|c|c|c|}
\hline $\begin{array}{l}\quad \text { Planning } \\
\text { 1. Identify the scope } \\
\text { 2. Identify the } \\
\text { characteristics of } \\
\text { students } \\
\text { 3. Prepare planning } \\
\text { documents } \\
\text { 4. Determine and } \\
\text { collect resources } \\
\text { 5. Brainstorming }\end{array}$ & $\begin{array}{l}\text { Design } \\
\text { 1. Initial content } \\
\text { development } \\
\text { 2. Perform task analysis } \\
\text { and concept analysis } \\
\text { 3. Prepare for making } \\
\text { flowcarts and } \\
\text { storyboards }\end{array}$ & $\begin{array}{l}\qquad \text { Develop } \\
\text { 1. Prepare text } \\
\text { 2. Make a video and audio } \\
\text { recording } \\
\text { 3. Putting material } \\
\text { 4. Prepare supporting } \\
\text { materials } \\
\text { 5. Making Program } \\
\text { 6. Perform the alpha test } \\
\text { 7. Revise } \\
\text { 8. Do a beta test } \\
\text { 9. Revise } \\
\text { 10. Perform product testing } \\
\text { / field trials }\end{array}$ \\
\hline
\end{tabular}

Gambar 1. Langkah-Langkah Model Pengembagan Alessi \& Trollip (2001).

The score of knowledge is to determine student learning outcomes to understand interactive physics digital handout media as a learning tool. At this stage, the student learning outcomes were in the form of a pretest before learning physics with interactive digital handouts and a post-test after learning physics with interactive digital handouts. The results of calculating the participant's pre-test and post-test scores are used to analyze the benefits obtained from the acquisition of $\mathrm{N}$ standards. The steps to analyze the learning test result data on learning devices using interactive digital physics material are as follows: 1) get the average score pre-test and post-test, 2) calculate the acquisition based on the pre-test and post-test scores; and 3) Classify the criteria for $\mathrm{N}$-gain results according to Table 1 . The category above is to determine the level of effectiveness of elearning device development. If $\mathrm{N}$ gain is high, the momentum and impulse of e-learning material using interactive digital physics are very effective. If moderate, e-learning materials on momentum and impulse using interactive digital physics are effective. If the $\mathrm{N}$ gain is low, momentum and impulse materials using interactive digital physics are less effective 
Table 1. Category of N-Gain Score acquisition (Fadaei, 2019)

\begin{tabular}{cc}
\hline Criteria for Category N-gain Score & Category \\
\hline If $N_{\text {gain }} \geq 0,7$ & High \\
If $0,7>N_{\text {gain }} \geq 0,3$ & Moderate \\
If $N_{\text {gain }}<0,3$ & Low \\
\hline
\end{tabular}

\section{Result and Discussion}

The beginning of the meeting was carried out by giving the pre-test questions. Students are given ten questions. Student pre-test results data can be seen in Table 1 as follows.

Table 1. Recapitulation of Pretest Results

\begin{tabular}{cccc}
\hline Interval Score & Number of participants & percentage & Predicate \\
\hline $90-100$ & 0 Student & $0 \%$ & Excellent \\
$80-89$ & 0 Student & $0 \%$ & Good \\
$60-79$ & 2 Student & $6,67 \%$ & Enough \\
$50-59$ & 3 Student & $10 \%$ & Bad \\
$0-49$ & 25 Student & $83,33 \%$ & Very Bad \\
\hline Total & 30 Student & $100 \%$ & \\
\hline
\end{tabular}

Based on the data above, many students do not understand momentum and impulse material, so they need to use interactive digital handout tools to improve their understanding during the learning process, improving students' learning abilities. After the media was developed later, testing the interactive digital handout on the momentum of physics material and physics impulses for senior high school. In terms of the development process, the validity of the interactive digital physics handout was tested after being tested through 3 aspects, namely material $(81.81 \%)$, media $(87.50 \%)$, and learning design $(90.90 \%)$. Based on these three categories, it can be seen that this interactive digital handout is valid and worthy of being tested with revisions according to the suggestions. Second, interactive digital physics handouts have been tested for practicality. It can be seen from the practicality test on three students. It obtained a very practical assessment $(83.33 \%)$ for each assessment by filling out a questionnaire. This physics interactive digital handout can be used for learning by getting a very practical assessment of physics momentum and impulse material.

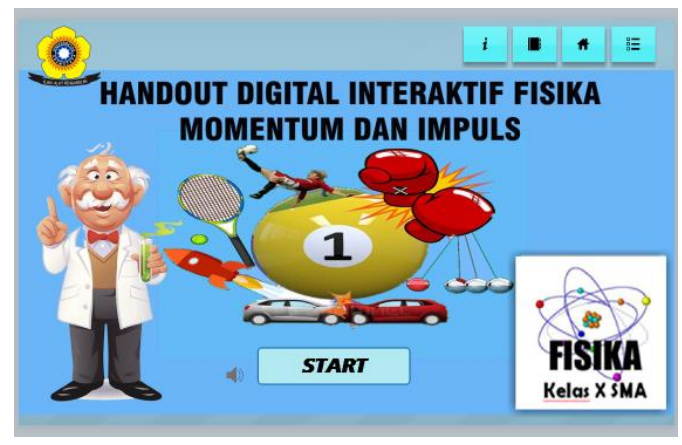

Figure 1. Interactive digital use of physics on momentum and impulses

Using interactive digital physics handouts, students carry out the learning process using interactive physics digital handout products. The post-test is given after the students have finished studying. The post-test implementation used ten randomized pre-test questions. Recapitulation of the post-test results can be seen in table 2.

Based on the data above, there was an increase in student learning outcomes after using the physics interactive digital handout, described in diagram 1.

Tabel 2. Recapitulation of Posttest Results

\begin{tabular}{cccc}
\hline Interval Score & Number of participants & percentage & \multicolumn{1}{c}{ Predicate } \\
\hline $90-100$ & 5 Student & $16,66 \%$ & Excellent \\
\hline $80-89$ & 16 Student & $53,33 \%$ & Good \\
\hline
\end{tabular}




\begin{tabular}{cccc}
\hline Interval Score & Number of participants & percentage & Predicate \\
\hline $60-79$ & 4 Student & $13,33 \%$ & Enough \\
\hline $50-59$ & 0 Student & $0 \%$ & Bad \\
\hline $0-49$ & 0 Student & $0 \%$ & Very Bad \\
\hline Total & 30 Student & $100 \%$ & \\
\hline
\end{tabular}

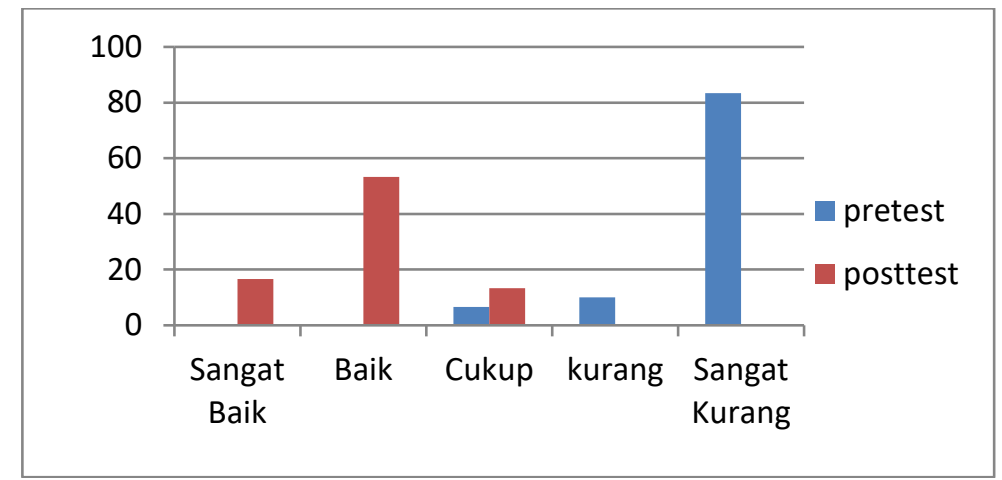

Diagram 1. Comparison of the Recapitulation Score of Pretest and Posttest Score

The comparison diagram of the pre-test and post-test recapitulation shows an increase in student learning outcomes in the pre-test activities before using the digital physics handouts and post-test after using the digital physics handouts. The pre-test and post-test will be analyzed according to the N-gain score. Assessment of effectiveness is measured using $\mathrm{N}$-gain based on the average pre-test and post-test scores, as shown in Table 4 below.

Table 4. Recapitulation of Pretest, Posttest, N-gain Mean

\begin{tabular}{|c|c|c|}
\hline 1 & Average Posttest & $\mathrm{N}$-gain \\
\hline 47,53 & 82,83 & 0,70 \\
\hline \multicolumn{2}{|c|}{ Category } & Moderate \\
\hline
\end{tabular}

The $\mathrm{N}$-gain result of 0.70 in the medium category shows that the use of physics interactive digital handouts in online learning of momentum and impulse material have a good effect on student learning outcomes. The high increase affects the use of interactive digital handouts in the learning process. It can be concluded that the interactive digital physics handouts developed are valid and feasible to apply. Several factors, as follows, cause it.

First, the interactive digital physics handouts that have been developed are feasible because using interactive digital handouts is very easy to help students learn. Learning media that are easy to apply make it easier for students to learn (Qondias, Anu, \& Niftalia, 2016; Rahmi, Budiman, \& Widyaningrum, 2019). The development of physics interactive digital handouts cannot be separated from learning theory. Learning theory studies how students learn, which determines their learning outcomes. In developing interactive digital physics handout products, pay attention to learning theories that can be used as guidelines in its development so that the products are made right on target and following the mindset of students. Theories that support the development of physics interactive digital handouts include cognitive learning theory, which focuses on students' thought processes and behaviors such as logic and memory (Mu'min, 2013; Paramitha, Sulastri, \& Margunayasa, 2016). According to this theory, knowledge is built in students through continuous interaction with the environment. Based on the student response questionnaire to the use of physics interactive digital handouts get a good response because it can be processed as desired, the material is easy to understand. The video examples are easy to follow and increase knowledge.

Second, the interactive digital physics handout that has been developed is feasible to apply because the material contained in the interactive digital physics handout is appropriate to make it easier for students to understand the subject matter. The suitability of the material presented in the teaching materials will make it easier for students to understand the lesson (Asrial et al., 2020; Diantari et al., 2018; Sadimin, Hardyanto, \& Slamet, 2017). Difficulties in understanding lessons are generally caused by educators' lack of innovative teaching materials in the learning process (Diantari et al., 2018; Suarsana, 2013). According to the material to be presented, the development of teaching materials is adjusted to formal operational development stages, such as explanations of both text and video, giving examples, and using other supporting content to facilitate students' 
understanding of the material. Furthermore, constructivist learning theory says it is a process of independent learning (Sobri, Nursaptini, \& Novitasari, 2020; Suryadewi, Wiyasa, \& Sujana, 2020). This learning theory holds that students can build their learning knowledge because they have a different view of the studied material. In this case, Senior High School students are at a formal operational stage where students can think abstractly, critically, and logically. This thinking ability can determine how students can understand a concept. Interactive teaching materials as teaching materials to support learning apply constructivist learning theory and are equipped with text, images, animation, and video content (Perdana, Sarwanto, Sukarmin, \& Sujadi, 2017; Safitri, 2017). Students can construct their knowledge and visualize both the material presented in the form of images and animations, making it easier for students to understand momentum and impulse material concepts.

Research conducted by Sugihartini \& Laba (2017) stated that teaching materials in interactive Emodules could help students understand the lesson. Research conducted by Irwandani et al., (2017b) stated that the interactive digital module could increase students' enthusiasm for learning. Research conducted by Serevina, Sunaryo, Raihanati, Sari, \& Juwita (2018) also stated that teaching materials in E-modules could improve students' learning abilities to improve student competence. So it can be concluded that interactive teaching materials can help students learn to improve student learning outcomes. This research implies that the teaching materials that have been developed can be applied by teachers in the learning process to improve student learning outcomes, especially in Physics subjects.

\section{Conclusion}

Based on experts' results, the interactive digital physics handouts developed are valid and feasible to be applied. Interactive digital physics handouts effectively improve the competence of Senior High School students, especially in physics subjects.

\section{References}

Alessi, S. M., \& Trollip, S. R. (2001). Multimedia For Learning: Methods And Development. European Journal of Education Studies, 1(1).

Asrial, Syahrial, Maison, Kurniawan, \& Piyana. (2020). Ethnoconstructivism E-Module to Improve Perception, Interest, And Motivation of Students in Class V Elementary School. Jurnal Pendidikan Indonesia, 9(1), 30-41. https://doi.org/10.23887/jpi-undiksha.v9i1.19222

Diani, R., \& Niken, S. H. (2018). Flipbook Berbasis Literasi Islam : Pengembangan Media Pembelajaran Fisika dengan 3d Pageflip Professional Flipbook Based On Islamic Literacy: The Development Of Physics Learning Media Using 3d Pageflip Professional." 4(2):234-44. Jurnal Inovasi Pendidikan IPA, 4(2). https://doi.org/https://doi.org/10.21831/jipi.v4i2.20819.

Diantari, Damayanthi, Sugihartini, \& Wirawan. (2018). Pengembangan E-modul berbasis Mastery Learning untuk Mata Pelajaran KKPI Kelas XI. Jurnal Nasional Pendidikan Teknik Informatika (Janapati), 7(1), 33-48. https://doi.org/http://dx.doi.org/10.23887/janapati.v7i1.12166.

Fadaei, A. S. (2019). Comparing Two Results: Hake Gain and Dellow Gain, to Analyze FCI Data in Active Learning Process. US-China Education Review A, 9(1). https://doi.org/10.17265/2161$623 x / 2019.01 .003$.

Fadillah, \& Jamilah. (2016). Pengembangan Bahan Ajar Struktur Aljabar Untuk Meningkatkan Kemampuan Pembuktian Matematis Mahasiswa. Cakrawala Pendidikan, 35(1), 106-108. https://doi.org/https://doi.org/10.21831/cp.v1i1.8379.

Hafsah, Rohendi, \& Purnawan. (2016). Penerapan Media Pembelajaran Modul Elektronik Untuk Meningkatkan Hasil Belajar Siswa Pada Mata Pelajaran Teknologi Mekanik. Journal of Mechanical Engineering Engineering Education, 3(1). https://doi.org/https://doi.org/10.17509/jmee.v3i1.3200.

Irwandani, I., Latifah, S., Asyhari, A., Muzannur, M., \& Widayanti, W. (2017a). Modul Digital Interaktif Berbasis Articulate Studio'13: Pengembangan pada Materi Gerak Melingkar Kelas X. Jurnal Ilmiah Pendidikan Fisika Al-Biruni, 6(2). https://doi.org/https://doi.org/10.24042/jipfalbiruni.v6i2.1862.

Irwandani, Latifah, Asyhari, Muzannur, \& Widayanti. (2017b). Modul Digital Interaktif Berbasis Articulate Studio'13: Pengembangan Pada Materi Gerak Melingkar Kelas X. Jurnal Ilmiah Pendidikan Fisika AlBiRuNi, 6(2). https://doi.org/10.24042/jipfalbiruni.v6i2.1862.

Izati, S. N., Wahyudi, \& Sugiyarti, M. (2018). Project Based Learning Berbasis Literasi untuk Meningkatkan Hasil Belajar Tematik. Jurnal Pendidikan: Teori, Penelitian, Dan Pengembangan, 3(9), 1122-11271127. https://doi.org/10.17977/jptpp.v3i9.11508.

Kimianti, \& Prasetyo. (2019). Pengembangn E-aModul Ipa Berbasis Problem Based Learning Untuk Meningkatkan Literasi Sains Siswa. Kwangsan Jurnal Teknologi Pendidikan, 7(2), 91-103. https://doi.org/http://doi.org/10.31800/jtp.kw.v7n2.p91--103. 
Lase, D. (2019). Pendidikan di Era Revolusi Industri 4.0. Jurnal Sundermaan, 1(1). https://doi.org/https://doi.org/10.36588/sundermann.v1i1.18.

Meilani, D., Dantes, N., \& Tika, I. N. (2020). Pengaruh Implementasi Pembelajaran Saintifik Berbasis Keterampilan Belajar dan Berinovasi 4C terhadap Hasil Belajar IPA dengan Kovariabel Sikap Ilmiah pada Peserta Didik Kelas V SD Gugus 15 Kecamatan Buleleng. Jurnal Elementary: Kajian Teori Dan Hasil Penelitian Pendidikan Sekolah Dasar, 3(1), 1-5. https://doi.org/https://doi.org/10.31764/elementary.v3i1.1412

Mu'min, S. A. (2013). Teori Perkembangan Kognitif Jean Piaget. Jurnal Al-Ta'dib, 6(1), 89-99. https://doi.org/http://dx.doi.org/10.31332/atdb.v6i1.292

Muhson, A. (2010). Pengembangan Media Pembelajaran Berbasis Teknologi Informasi. Jurnal Pendidikan Akuntansi Indonesia, 8(2), 2. https://doi.org/https://doi.org/10.21831/jpai.v8i2.949

Paramitha, I. D. A. A., Sulastri, M. P., \& Margunayasa, I. G. (2016). Pengaruh Model Inkuiri Terbimbing, Gaya Kognitif, dan Motivasi Berprestasi terhadap Pemahaman Konsep IPA Siswa Kelas V SD. MIMBAR PGSD Undiksha, 4(1), 1-11. https://doi.org/10.23887/jppundiksha.v49i2.9012

Perdana, Sarwanto, Sukarmin, \& Sujadi. (2017). Development of E-Module Combining Science Process Skills And Dynamics Motion Material To Increasing Critical Thinking Skills And Improve Student Learning Motivation Senior High School. International Journal of Science and Applied Science, 1(1), 45-54. https://doi.org/10.20961/ijsascs.v1i1.5112

Pramana, Jampel, \& Pudjawan. (2020). Meningkatkan Hasil Belajar Biologi Melalui E-Modul Berbasis Problem Based Learning. Jurnal Edutech Undiksha, https://doi.org/http://dx.doi.org/10.23887/jeu.v8i2.28921

Purnomo, Ratnawati, \& Aristin. (2016). Pengembangan Pembelajaran Blended Learning Pada Generasi Z. JTP2JPS, 1(1). https://doi.org/http://dx.doi.org/10.17977/um022v1i12016p070

Qondias, Anu, \& Niftalia. (2016). Pengembangan Media Pembelajaran Tematik Berbasis Mind Mapping SD Kabupaten Ngada Flores. Jurnal Pendidikan Indonesia, 5(2), 176--182. https://doi.org/http://dx.doi.org/10.23887/jpi-undiksha.v5i2.8590

Rafmana, H., \& Chotimah, U. (2018). Pengembangan Multimedia Interaktif Berbasis Articulate Storyline untuk Meningkatkan Motivasi SMA Srijaya Negara Palembang. Jurnal Bhinneka Tunggal Ika, 5(1). Retrieved from https://ejournal.unsri.ac.id/index.php/jbti/article/view/7898/pdf

Rahmi, M. S. M., Budiman, M. A., \& Widyaningrum, A. (2019). Pengembangan Media Pembelajaran Interaktif Macromedia Flash 8 Pada Pembelajaran Tematik Tema Pengalamanku. International Journal Of Elementary Education, 3(2), 178-185. https://doi.org/10.23887/ijee.v3i2.18524

Rastati, R. (2018). Media Literasi Bagi Digital Natives: Persektif Generasi Z Di Jakarta. Kwangsan: Jurnal Teknologi PendidikanJurnal Teknologi https://doi.org/https://doi.org/10.31800/jtp.kw.v6n1.p60--73

Sadimin, Hardyanto, \& Slamet. (2017). Developing An E-Module-Based Classroom Action Research Management Training Model For Teachers High School. International Journal of Education and Research, 5(2), 79-90. Retrieved from https://journal.unnes.ac.id/sju/index.php/jed/article/view/18123

Safitri, I. (2017). Pengembangan E-Module Dengan Pendekatan Pembelajaran Matematika Realistik Berbantuan Flipbook Maker Pada Materi Bangun Ruang Sisi Datar Kelas Viii Smp. Aksioma, 6(2), 1. https://doi.org/10.26877/aks.v6i2.1397

Serevina, Sunaryo, Raihanati, Sari, \& Juwita. (2018). Development of E-module Based on Problem Based Learning (PBL) on Heat and Temperature to Improve Student's Science Process Skill'. Turkish Online Journal of Educational Technology-TOJET, 17(3), 26-36. Retrieved from https://eric.ed.gov/?id=EJ1184205

Sobri, M., Nursaptini, N., \& Novitasari, S. (2020). Mewujudkan Kemandirian Belajar Melalui Pembelajaran Berbasis Daring Diperguruan Tinggi Pada Era Industri 4.0. Jurnal Pendidikan Glasser, 4(1), 64. https://doi.org/10.32529/glasser.v4i1.373

Suarsana, I. M. (2013). Pengembangan E-Modul Berorientasi Pemecahan Masalah Untuk Meningkatkan Keterampilan Berpikir Kritis Mahasiswa. JPI (Jurnal Pendidikan Indonesia), 2(2), 264-275. https://doi.org/10.23887/jpi-undiksha.v2i2.2171

Subandowo, M. (2017). Peradaban dan Produktivitas dalam Perspektif Bonus Demografi serta Generasi Y dan Z. Sosiohumanika: Jurnal Pendidikan Sains Sosial Dan Kemanusiaan, 10(2). https://doi.org/https://doi.org/10.2121/sosiohumanika.v10i2.920

Sugihartini, \& Laba. (2017). Pengembangan E-modul mata kuliah strategi pembelajaran. Jurnal Pendidikan Teknologi Dan Kejuruan, 14(2), 221-230.

Suryadewi, N. K. A., Wiyasa, I. K. N., \& Sujana, I. W. (2020). Kontribusi Sikap Mandiri dan Hubungan Sosial Terhadap Kompetensi Pengetahuan IPS. MIMBAR PGSD Undiksha, 8(1), $29-39$. https://doi.org/http://dx.doi.org/10.23887/jjpgsd.v8i1.24576 
Syafii. (2017). Pengembangan Bahan Ajar Ornamen Berbasis Candi di Jawa Tengah: Studi Identifikasi Candi Gedongsanga. Imajinasi Jurnal Seni, https://doi.org/https://doi.org/10.15294/imajinasi.v11i2.12813.

Udayana, Wirawan, \& Divayana. (2017). Pengembangan E-modul pada mata pelajaran pemrograman berorientasi objek dengan model pembelajaran Problem Based Learning Kelas VIII rekayasa perangkat lunak. Jurnal Nasional Pendidikan Teknik Informatika (Janapati), 6(2), 128-139. https://doi.org/https://www.researchgate.net/deref/http\%3A\%2F\%2Fdx.doi.org\%2F10.23887\%2Fjanap ati.v6i2.9373

Warsihna, J. (2016). Meningkatkan Literasi Membaca dan Menulis dengan Teknologi Informasi dan Komunikasi. Kwangsan, 4(2), 67 - 80. https://doi.org/https://doi.org/10.31800/jtp.kw.v4n2.p67--80

Willya, Poluakan, Dikayuana, Wibowo, \& Raharjo. (2019). Generasi Milenial Pada Era Revolusi Industri 4.0. Focus : Jurnal Pekerjaan Sosial, 2(2). https://doi.org/https://doi.org/10.24198/focus.v2i2.26241.

Wulandari, Sudatha, \& Simamora. (2020). Pengembangan Pembelajaran Blended Pada Mata Kuliah Ahara Yoga Semester II di IHDN Denpasar. Jurnal Edutech Undiksha, 8(1), 1-15. https://doi.org/http://dx.doi.org/10.23887/jeu.v8i1.26459

Yasin, A. N., \& Ducha, N. (2017). Kelayakan Teoritis Multimedia Interaktif Berbasis Articulate Storyline Materi Sistem Reproduksi Manusia Kelas XI SMA. Jurnal Bioedukatika, 6(2). Retrieved from https://jurnalmahasiswa.unesa.ac.id/index.php/bioedu/article/view/20868 